\title{
Carcinosarcoma of the Sigmoid Colon: Report of a Case
}

\author{
Yasuharu Moria Kenji Katsumata $^{a}$ Shouji Suzukia \\ Daisuke Matsuda $^{\mathrm{a}}$ Tomonori Hara ${ }^{\mathrm{a}}$ Yasuharu Hayashida ${ }^{\mathrm{a}}$ \\ Masanobu Enomoto ${ }^{a}$ Tatehiko Wada ${ }^{a}$ Akihiko Tsuchida ${ }^{a}$ \\ Tatsuya Aoki $^{\mathrm{a}}$ Tsuyoshi Saitou $^{\mathrm{b}}$ Jun Matsubayashi ${ }^{\mathrm{b}}$ \\ Hiroshi Kusama ${ }^{b}$
}

aDivision of Gastroenterological Surgery and bepartment of Pathology,

Tokyo Medical University Hospital, Tokyo, Japan

\section{Key Words}

Carcinosarcoma $\cdot$ Colorectal tumor $\cdot$ Mesenchymal tumor

\begin{abstract}
Our case was a 65-year-old male, with the chief complaints of diarrhea and abdominal distention. Three years earlier, the patient had undergone transcatheter arterial embolization and radiofrequency treatment based on a diagnosis of hepatocellular carcinoma due to hepatitis B by another doctor. In October 2007, the patient developed diarrhea and increased abdominal distention. In December, CT examination conducted by the previous doctor revealed a $20-\mathrm{cm}$ tumor within the pelvis. The patient was diagnosed with sigmoid colon cancer based on barium enema examination using gastrografin, and was introduced to our hospital for treatment. He was diagnosed with low-differentiated carcinoma by biopsy of the colon during endoscopy and underwent sigmoidectomy based on a diagnosis of sigmoid colon cancer. The tumor had infiltrated the bladder, and a tumorectomy was conducted through partially combined resection. The tumor was a huge lesion occupying the inside of the lumen, and histopathological findings revealed that the tumor, the main part of which lay beneath the mucous membrane, had a transitional image composed of both spindle-shaped atypical cells and sarcomatoid shape. The result of immunostaining was CK7(+), CK20(-), AFP(-), and the patient was diagnosed as having carcinosarcoma of the colon. Carcinosarcoma of the colon is a malignant tumor with poor prognosis, and the mean survival period in past reports was approximately 6 months. The patient was treated with FOLFIRI+Bevacizumab therapy according to chemotherapy for colon cancer, but he was refractory to the therapy.
\end{abstract}




\begin{tabular}{r|l|l|l}
$\begin{array}{r}\text { Case Reports in } \\
\text { Gastruanteriology }\end{array}$ & $\begin{array}{l}\text { Case Rep Gastroenterol 2010;4:484-491 } \\
\text { DOI: 10.1159/000318739 }\end{array}$ & $\begin{array}{l}\text { Published online: } \\
\text { November 3, 2010 }\end{array}$ & $\begin{array}{l}\text { O 2010 S. Karger AG, Basel } \\
\text { ISSN 1662-0631 } \\
\text { www.karger.com/crg }\end{array}$ \\
\hline
\end{tabular}

\section{Introduction}

Carcinosarcoma is a relatively rare tumor characterized by a mixed composition of malignant epithelial and mesenchymal components with a poor prognosis. This tumor occurs in various anatomic locations such as head and neck, respiratory tract, uterus, ovaries and other sites. Within the digestive tract, it is most often seen in the esophagus. Carcinosarcoma of the colon was first reported by Weidner and Zekan in 1986 [1], and since then fewer than 20 cases have been reported. In this paper we report a case with carcinosarcoma of the colon found during treatment for hepatic cancer. Carcinosarcoma of the colon is a very rare disease and we discuss it with reference to the literature.

\section{Case Report}

The patient was a 65-year-old male presenting with the chief complaints of feeling of oppression in the lower abdomen and diarrhea. He had a past history of hepatitis B, hepatic cell carcinoma and hypertension. His family history was unspecific. Diarrhea occurred from October 2007, and abdominal distention developed from December. The patient had been diagnosed as having colon cancer by the previous doctor. He visited us for surgery and treatment, wished to undergo surgery in our hospital, and so was admitted. His height was $167.3 \mathrm{~cm}$ and his weight was $58.0 \mathrm{~kg}$. Nutritional state was slightly poor. Blood pressure was $88 / 59 \mathrm{~mm} \mathrm{Hg}$, pulse rate was $96 \mathrm{bpm}$ and regular, and the bulbar conjunctiva and palpebral conjunctiva were normal. There was no swelling of superficial lymph nodes. The abdomen was swollen and a mass was palpated in the lower abdomen. Findings on admission were: anemia with $\mathrm{Hb} 10.2 \mathrm{~g} / \mathrm{dl}$, CEA $2.3 \mathrm{IU} / \mathrm{ml}$, CA19-9 $36.0 \mathrm{ng} / \mathrm{ml}$ and AFP $18.0 \mathrm{ng} / \mathrm{ml}$. Barium enema examination showed a mass being compressed from the outside of the wall in the sigmoid colon (fig. 1). Colon endoscopy revealed a smooth granulation-like mass with glazed surface projecting within the lumen at about $15 \mathrm{~cm}$ from the anal verge (fig. 2). The tumor was elastic and soft, and it was difficult to insert the fiber through it to the oral bowel. In an image of the tumor tissue by biopsy, proliferation of atypical cells was observed in part of the degenerated or necrotic tissues, which was diagnosed as undifferentiated cancer. Immunostaining was additionally conducted and was positive for cytokeratin 7 and negative for cytokeratin 20, hepatocyte and AFP. CT revealed a mass of approximately $15 \mathrm{~cm}$ within the pelvis whose inside was inhomogeneous and whose boundary was comparatively distinct. Contrast effect was observed on the margins. There were no distinct infiltrations into the other organs (fig. 3 ). MRI also depicted it as a mass with a distinct boundary and inhomogeneous inside. Based on the above findings, surgery was conducted under the diagnosis of undifferentiated cancer of the colon.

Surgical findings showed that the mass originated from the sigmoid colon, and part of it infiltrated the bladder, so part of the bladder was resected together with the mass. Intraoperatively, a small white nodule was observed in part of the greater omentum, which was diagnosed as peritoneal semination by intraoperative rapid diagnosis. None of the 26 extracted lymph nodes developed metastasis, and surgical stage was SiN0H0P1M(-), stage IV according to the General Rules for Clinical and Pathological Studies on Cancer of the Colon, Rectum and Anus. The solid cut surface of the lesion showed that the tumor was submucosal and part of it became necrotic with bleeding (fig. 4).

The HE finding revealed that atypical epithelial cells had various sizes of duct structure, forming an alveolar structure. Partly spindle-shape atypical cells had proliferated and formed a sarcomatoid shape, but there were no ectopic mesenchymal components of bone, cartilage, and striated muscle. There was a transitional zone, though slightly indistinct, between the epithelial tumor part and mesenchymal tumor part with a component ratio of 9:1 between the former and the latter (fig. 5 ). Immunostaining was positive for cytokeratin 7 , negative for cytokeratin 20 , partially positive for hepatocyte, which is a marker of hepatic cell cancer, negative for AFP, and negative for PAS, which is a marker of mucinous carcinoma, thus disproving colon metastasis of hepatic cell cancer. hCG was negative and so there was no possibility of germinoma. Based on the above, the disease was diagnosed as low-differentiated tumor showing differentiation into various tissues such as glandular epithelium or hepatic cells. The diagnosis according to the General Rules for Clinical and Pathological Studies on Cancer of the Colon, Rectum and Anus was SE, int, INFb, ly0, v2, n0(0/26), H0, P1, M(-), stage IV. 


\begin{tabular}{r|l|l|l} 
Case Reports in & $\begin{array}{l}\text { Case Rep Gastroenterol 2010;4:484-491 } \\
\text { DOI: 10.1159/000318739 }\end{array}$ & $\begin{array}{l}\text { Published online: } \\
\text { November 3, 2010 }\end{array}$ & $\begin{array}{l}\text { I 2010 S. Karger AG, Basel } \\
\text { ISS62-0631 } \\
\text { www.karger.com/crg }\end{array}$ \\
\hline
\end{tabular}

Postoperatively the patient was discharged from the hospital 44 days after surgery without postoperative complications. He had orally been administered capecitabine $3,000 \mathrm{mg} /$ day as adjuvant chemotherapy, but multiple lung metastases occurred bilaterally at 6 months after surgery.

Chemotherapy of FOLFIRI+Bevacizumab was started and 8 cycles were conducted, but the effect was determined as PD, and the patient died on October 21, 2008.

\section{Discussion}

Carcinosarcoma of the colon is a malignant tumor composed of both carcinoma and sarcoma components. In the literature, carcinosarcoma occurring in the colon was first reported by Weidner and Zekan in 1986 [1]. To our knowledge, there have been reports of 19 cases to date (table 1 ). The mean age of patients was 69.1 years without any difference between males and females. No significant difference was observed in the ratio between carcinoma and sarcoma components. Lesions of carcinosarcoma were found in various places including the abdominal organs, skin, lung, mammary gland, eye, and head or neck, but its pathopoiesis remains unclear when compared with other malignant tumors. The mean survival period was as short as 6 months, showing extremely poor prognosis (fig. 6). The subject in this study was treated with positive chemotherapy upon occurrence of lung metastasis, but died 5 months later.

There are three histological theories: collision theory, composition theory, and combination theory. The combination theory has two subtheories: the metaplastic tumor theory which considers that the sarcoma component is secondarily derived from carcinoma, and the conversion tumor theory. With regard to carcinosarcomas which develop in the digestive system organs, the metaplastic theory is supported, which explains that in most cases, the carcinoma component precedes and that it is differentiated into the sarcomatoid component in accordance with the development of cancer clones [21]. A similar finding was reported for carcinosarcomas in the lung or bladder $[22,23]$. Analyses of the inactivation pattern of X chromosome, P53, and LOH clarified that many patients with carcinosarcoma had combination tumor deriving from a single clone. A past report described that the epithelial component and sarcoma component of carcinosarcoma in the colon were classified into a weak positive sarcoma component, osteosarcomatoid component, and chondrosarcoma component without the former two components by staining cytokeratin using HE staining and immunostaining methods, and their prognoses were compared. Aramendi et al. [15] reported that there was heterologous differentiation in the osteo- and chondrosarcomatous areas and the prognosis of this group was uniformly dismal, and that in most cases, the timing of operation was correlated with its prognosis, and there was no case affecting the prognosis, though chemotherapy and radiotherapy were conducted after tumorectomy. In this patient, heterologous differentiation of osteo- and chondrosarcomatous areas was observed in the mesenchymal component. With regard to chemotherapy, 5-FU FL therapy (UFT+leucovorin), and capecitabine, or MMC, cisplatin have been administered to patients with metastasis in lymph nodes in accordance with colon cancer therapy, but a satisfactory treatment effect has not been obtained as yet $[1,6,8,12,13,18]$. This patient had been orally administered capecitabine as postoperative adjuvant chemotherapy, but multiple lung metastases were observed by PET examination conducted 6 months after surgery. FOLFIRI (5-FU, 1-LV, Irinotecan), which is the standard chemotherapy for progressive recurrent colon cancer, and Bevacizumab, which is a molecular target drug, were administered, but there was no treatment effect and metastatic lesions rapidly 


\begin{tabular}{r|l|l|l} 
Case Reports in & $\begin{array}{l}\text { Case Rep Gastroenterol 2010;4:484-491 } \\
\text { DOI: } 10.1159 / 000318739\end{array}$ & $\begin{array}{l}\text { Published online: } \\
\text { November 3, 2010 }\end{array}$ & $\begin{array}{l}\text { ISSN 1662-0631 } \\
\text { ISww.karger.com/crg }\end{array}$ \\
\hline
\end{tabular}

increased, and the patient died 10 months after surgery. Currently, the range of choice of therapeutic agents for progressive recurrent colon cancer has been spreading because of the emergence of molecular target drugs such as cetuximab, and therapeutic agents that are effective for carcinosarcoma are expected to become available on the market.

Table 1. Cases of carcinosarcoma of the colon reported in the literature

\begin{tabular}{|c|c|c|c|c|c|c|c|c|c|}
\hline $\begin{array}{l}\text { Refer- } \\
\text { ence }\end{array}$ & Age/sex & Site & $\begin{array}{l}\text { Distant } \\
\text { metastasis }\end{array}$ & Component & $\begin{array}{l}\mathrm{LN} \\
\text { metastasis }\end{array}$ & $\begin{array}{l}\text { Out- } \\
\text { come }\end{array}$ & Months & Year & $\begin{array}{l}\text { First } \\
\text { author }\end{array}$ \\
\hline 1 & $73 / \mathrm{M}$ & $\mathrm{S}$ & meta & - & - & dead & 48 & 1986 & Weidner \\
\hline 2 & $64 / \mathrm{M}$ & $\mathrm{D}$ & meta & $\mathrm{SC}>\mathrm{Ca}$ & + & dead & 4 & 1995 & Staroz \\
\hline 3 & $71 / \mathrm{F}$ & $\mathrm{R}$ & meta & $\mathrm{SC}>\mathrm{Ca}$ & + & dead & 6 & 1995 & Roncaroli \\
\hline 4 & $86 / \mathrm{F}$ & A & none & $\mathrm{Ca}>\mathrm{SC}$ & - & alive & 24 & 1996 & Isimbaldi \\
\hline 5 & $40 / \mathrm{F}$ & $\mathrm{C}$ & & - & & dead & 2 & 1997 & Gentile \\
\hline 6 & $79 / \mathrm{F}$ & A & sync & - & + & dead & 5 & 1997 & Bertram \\
\hline 7 & $69 / F$ & $\mathrm{D}$ & none & $\mathrm{SC}>\mathrm{Ca}$ & - & alive & 6 & 1997 & Serio \\
\hline 8 & $78 / \mathrm{M}$ & $\mathrm{D}$ & none & - & - & alive & 16 & 1998 & Shoji \\
\hline 9 & $60 / \mathrm{F}$ & $\mathrm{T}$ & none & $\mathrm{SC}>\mathrm{Ca}$ & + & alive & 14 & 1998 & Nakao \\
\hline 10 & $82 / \mathrm{M}$ & $\mathrm{R}$ & meta & $\mathrm{Ca}>\mathrm{SC}$ & - & dead & 6 & 2000 & Takeyoshi \\
\hline 11 & $57 / \mathrm{F}$ & $\mathrm{R}$ & sync & $\mathrm{SC}>\mathrm{Ca}$ & + & dead & 5 & 2001 & Shah \\
\hline 12 & $41 / \mathrm{F}$ & $S$ & none & $\mathrm{Ca}>\mathrm{SC}$ & + & dead & 4 & 2001 & Kim \\
\hline 13 & $56 / \mathrm{F}$ & $\mathrm{D}$ & meta & - & & dead & 21 & 2001 & Di Vizio \\
\hline 14 & $80 / \mathrm{F}$ & $\mathrm{R}$ & meta & $\mathrm{SC}>\mathrm{Ca}$ & + & dead & 6 & 2003 & Ishida \\
\hline 15 & $84 / \mathrm{M}$ & $\mathrm{T}$ & none & $\mathrm{Ca}>\mathrm{SC}$ & - & dead & 0 & 2003 & Aramendi \\
\hline 16 & $67 / \mathrm{F}$ & $S$ & meta & - & & dead & 2 & 2004 & Macaigne \\
\hline 17 & $71 / \mathrm{M}$ & $\mathrm{A}$ & sync & $\mathrm{Ca}>\mathrm{SC}$ & + & alive & - & 2005 & Kim \\
\hline 18 & $81 / \mathrm{M}$ & A & sync & $\mathrm{Ca}>\mathrm{SC}$ & + & alive & 24 & 2006 & Ambrosini \\
\hline 19 & $65 / F$ & $\mathrm{R}$ & none & $\mathrm{Ca}>\mathrm{SC}$ & - & alive & 60 & 2006 & Ozturk \\
\hline 20 & $13 / \mathrm{F}$ & $\mathrm{R}$ & meta & $\mathrm{SC}>\mathrm{Ca}$ & + & alive & 4 & 2008 & Jeong \\
\hline 21 & $74 / \mathrm{M}$ & $\mathrm{S}$ & meta & $\mathrm{Ca}>\mathrm{SC}$ & - & dead & 10 & & this report \\
\hline
\end{tabular}

meta $=$ Metachronous; sync $=$ synchronous $; \mathrm{SC}=$ sarcoma $\mathrm{Ca}=$ carcinoma; $\mathrm{S}=$ sigmoid; $\mathrm{D}=$ descending; $\mathrm{R}=$ rectum; $\mathrm{A}=$ ascending; $\mathrm{C}=$ cecum; $\mathrm{T}$ = transverse. 


\begin{tabular}{r|l|l|l}
$\begin{array}{r}\text { Case Reports in } \\
\text { Gastroenterology }\end{array}$ & $\begin{array}{l}\text { Case Rep Gastroenterol 2010;4:484-491 } \\
\text { DOl: 10.1159/000318739 }\end{array}$ & $\begin{array}{l}\text { Published online: } \\
\text { November 3, 2010 }\end{array}$ & $\begin{array}{l}\text { O 2010 S. Karger AG, Basel } \\
\text { ISSN 162-0631 } \\
\text { www.karger.com/crg }\end{array}$ \\
\hline
\end{tabular}

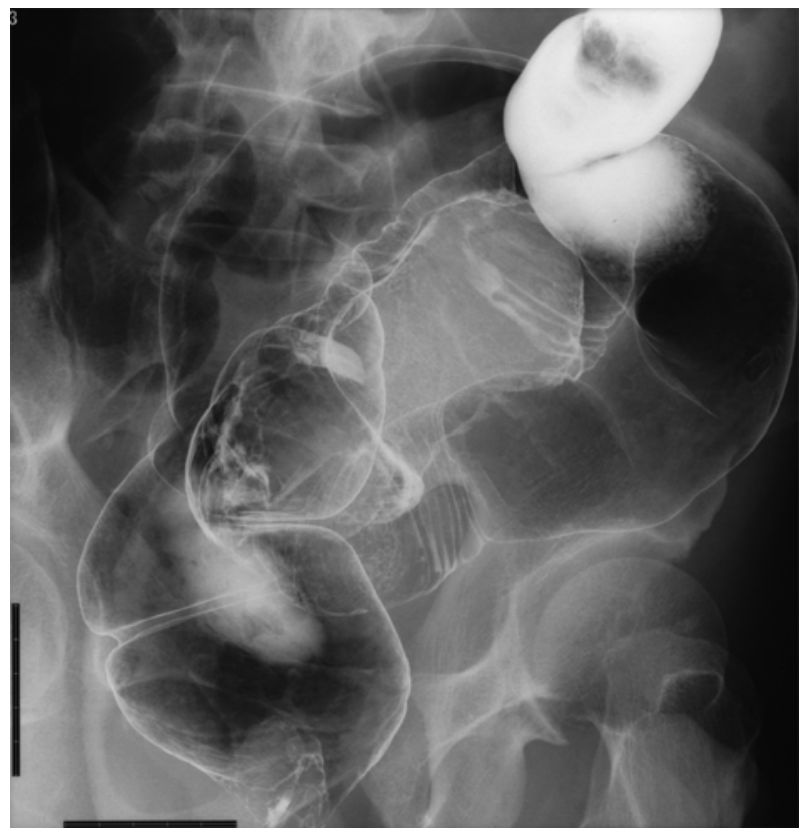

Fig. 1. Barium enema examination showed a mass being compressed from the outside of the wall in the sigmoid colon.

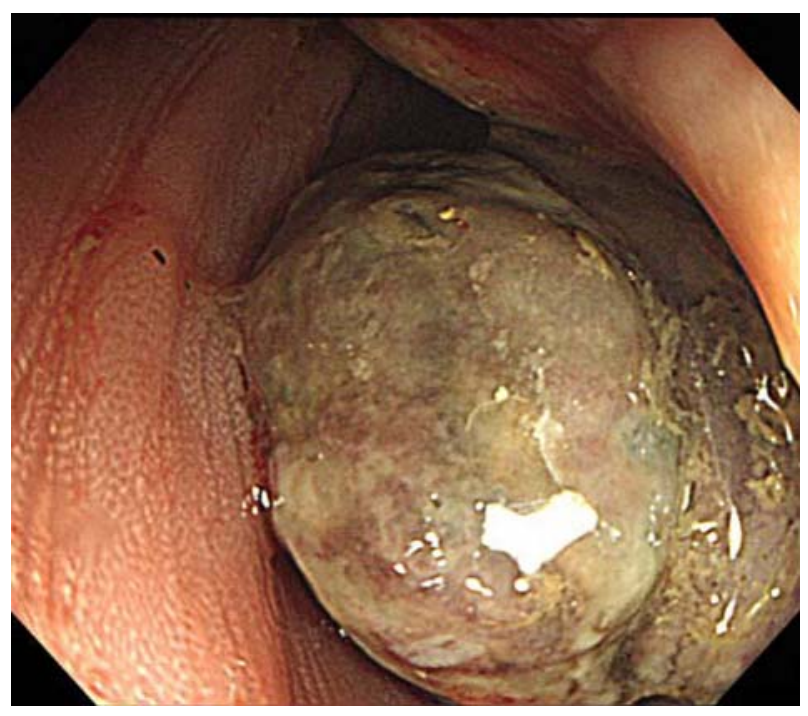

Fig. 2. Colon endoscopy showed a smooth granulation-like mass with glazed surface projecting within the lumen at about $15 \mathrm{~cm}$ from the anal verge. 


\begin{tabular}{r|l|l|l}
$\begin{array}{r}\text { Case Reports in } \\
\text { Gastroenterology }\end{array}$ & $\begin{array}{l}\text { Case Rep Gastroenterol 2010;4:484-491 } \\
\text { DOl: 10.1159/000318739 }\end{array}$ & $\begin{array}{l}\text { Published online: } \\
\text { November 3, 2010 }\end{array}$ & $\begin{array}{l}\text { O 2010 S. Karger AG, Basel } \\
\text { ISSN 1662-0631 } \\
\text { www.karger.com/crg }\end{array}$ \\
\hline
\end{tabular}

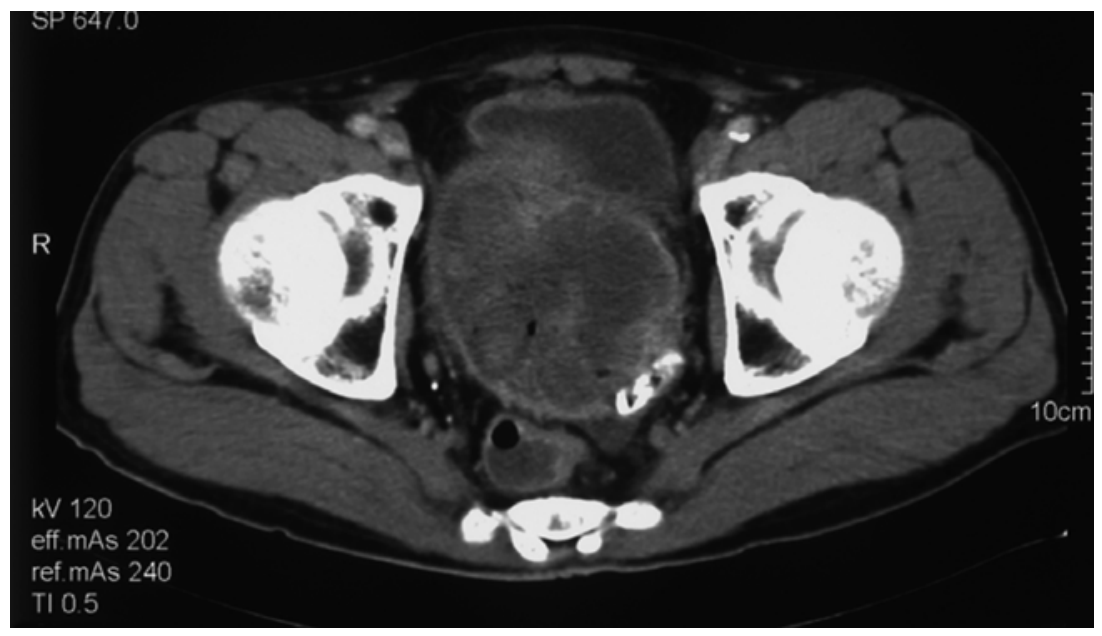

Fig. 3. Abdominal enhanced CT shows a ring-like enhanced and central heterogeneous tumor in the pelvis.

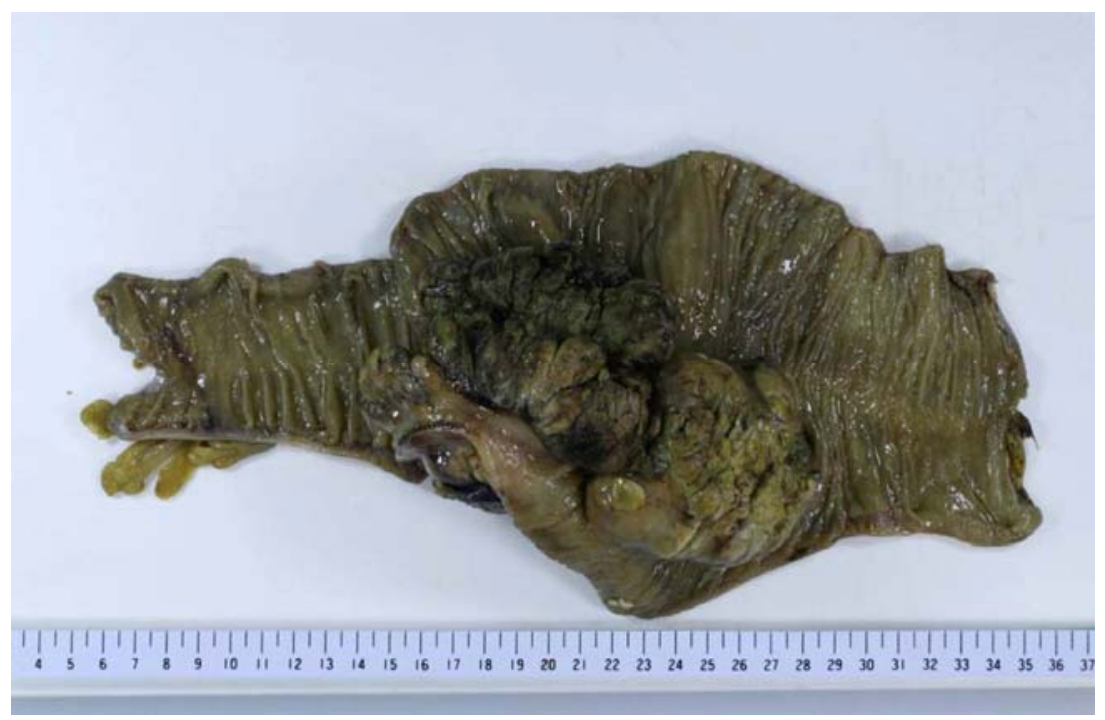

Fig. 4. The solid cut surface of the lesion showed that the tumor was submucosal and part of it became necrotic with bleeding. 


\begin{tabular}{r|l|l|l} 
Case Reports in & $\begin{array}{l}\text { Case Rep Gastroenterol 2010;4:484-491 } \\
\text { DOI: 10.1159/000318739 }\end{array}$ & $\begin{array}{l}\text { Published online: } \\
\text { November 3, 2010 }\end{array}$ & $\begin{array}{l}\text { ISSN 1662-0631 Karger AG, Basel } \\
\text { ISSw.karger.com/crg } \\
\text { wastraenteroloyy }\end{array}$ \\
\hline
\end{tabular}

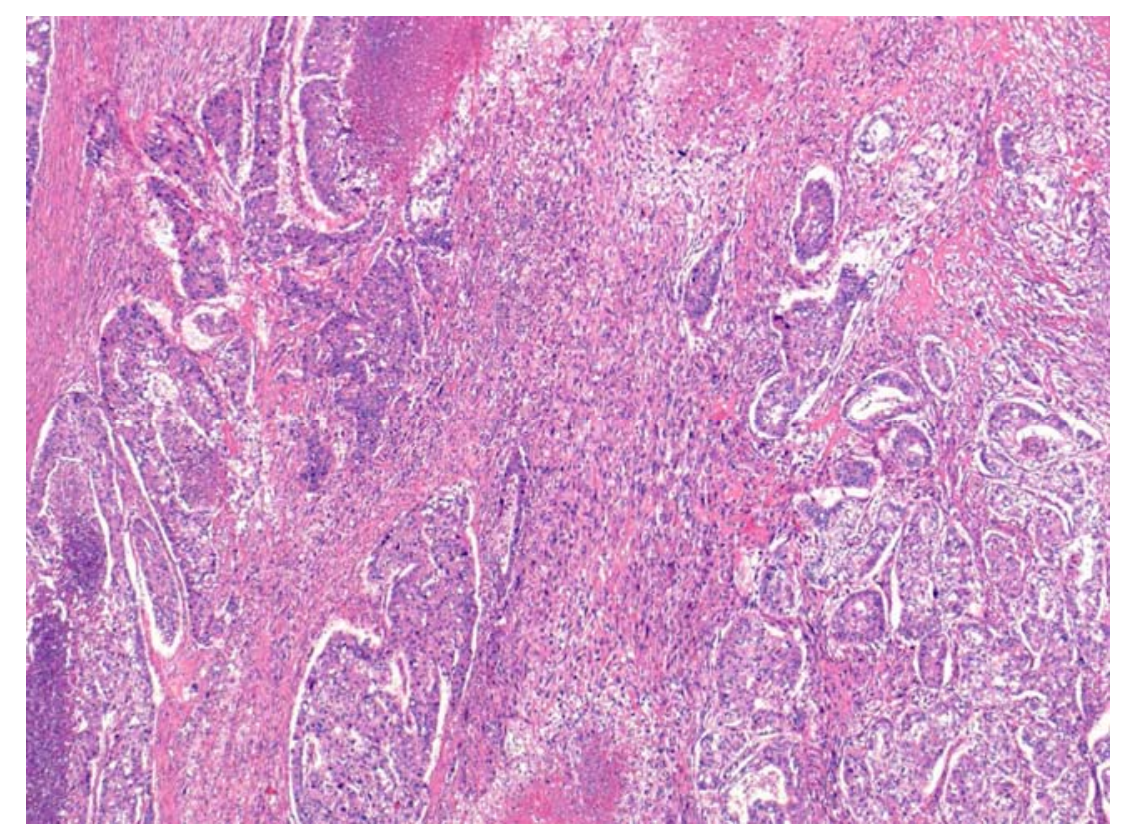

Fig. 5. There was a transitional zone, though slightly indistinct, between the epithelial tumor part and the mesenchymal tumor part. HE. $\times 25$.

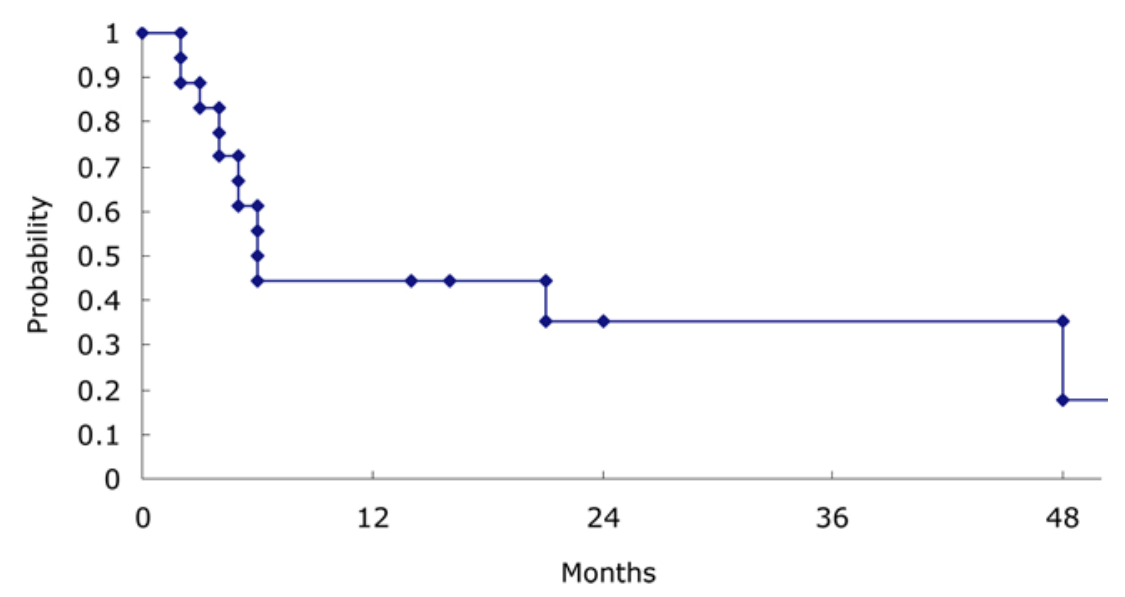

Fig. 6. Overall survival rate of reported cases of carcinosarcoma of the colon.

\section{References}

1 Weidner N, Zekan P: Carcinosarcoma of the colon. Report of a unique case with light and immunohistochemical studies. Cancer 1986;58:1126-1130.

2 Staroz F, Botton A, Potet F: Malignant tumors of the colon with two components (carcinosarcoma). Ann Pathol 1995;15:457-458.

3 Roncaroli F, Montironi R, Feliciotti F: Sarcomatoid carcinoma of the anorectal junction with neuroendocrine and rhabdomyoblastic features. Am J Surg Pathol 1995;19:217-223.

4 Isimbaldi G, Sironi M, Assi A: Sarcomatoid carcinoma of the colon. Report of the second case with immunohistochemical study. Pathol Res Pract 1996;192:483-487. 
5 Gentile R, Castellaneta A: Carcinosarcoma of the colon, one or two tumors? Pathologica 1997;89:62-68.

6 Bertram P, Treutner KH, Tietze L: True carcinosarcoma of the colon. Case report. Langenbecks Arch Chir 1997;382:173-174.

7 Serio G, Aguzzi A: Spindle and giant cell carcinoma of the colon. Histopathology 1997;30:383-385.

8 Shoji M, Dobashi Y, Iwabuchi K: Sarcomatoid carcinoma of the descending colon - a histological, immunohistochemical and ultrastructural analysis. Acta Oncol 1998;37:765-768.

-9 Nakao A, Sakagami K, Uda M: Carcinosarcoma of the colon: report of a case and review of the literature. J Gastroenterol 1998;33:276-279.

10 Takeyoshi I, Yoshida M, Ohwada S: Skin metastasis from the spindle cell component in rectal carcinosarcoma. Hepatogastroenterology 2000;47:1611-1614.

11 Shah S, Kim DH, Harster G: Carcinosarcoma of the colon and spleen: a fleshy purple mass on colonoscopy. Dig Dis Sci 2001;46:106-108.

12 Kim JH, Moon WS, Kang MJ: Sarcomatoid carcinoma of the colon: a case report. J Korean Med Sci 2001;16:657-660.

13 Di Vizio D, Insabato L, Conzo G: Sarcomatoid carcinoma of the colon: a case report with literature review. Tumori 2001;87:431-435.

14 Ishida H, Ohsawa T, Nakada H: Carcinosarcoma of the rectosigmoid colon: report of a case. Surg Today 2003;33:545-549.

15 Aramendi T, Fernandez-Acenero MJ, Villanueva MC: Carcinosarcoma of the colon: report of a rare tumor. Pathol Res Pract 2003;199:345-348.

16 Macaigne G, Aouad K, Boivin JF: Sarcomatoid carcinoma of the colon: report of a case and review of the literature. Gastroenterol Clin Biol 2004;28:600-604.

17 Kim N, Luchs JS, Halpern D: Radiology-Pathology Conference: carcinosarcoma of the colon. Clin Imaging 2005;29:259-262.

18 Ambrosini-Spaltro A, Vaira V, Braidotti P: Carcinosarcoma of the colon: report of a case with morphological, ultrastructural and molecular analysis. BMC Cancer 2006;6:185.

-19 Ozturk E, Yilmazlar T, Yerci O: A rare tumor located in the anorectal junction: sarcomatoid carcinoma. Turk J Gastroenterol 2006;17:236-239.

20 Jeong YJ, Lee MR, Kim JC, Hwang PH: Carcinosarcoma of the rectosigmoid colon in a 13-year-old girl. Pathol Int 2008;58:445-450.

21 Matsumoto T, Fujii H, Arakawa A: Loss of heterozygosity of analysis shows monoclonal evolution with frequent genetic progression and divergence in esophageal carcinosarcoma. Hum Pathol 2004;35:322-327.

22 Dacic S, Finkelstein SD, Sasatomi E: Molecular pathogenesis of pulmonary carcinosarcoma as determinded by microdissection-based allelotyping. Am J Surg Pathol 2002;26:510-516.

23 Halachmi S, DeMarzo AM, Chow NH: Genetic alterations in urinary bladder carcinosarcoma: evidence of a common clonal origin. Eur Urol 2000;37:350-357. 